MICHIGAN RETIREMENT AND DISABILITY RESEARCH CENTER UNIVERSITY OF MICHIGAN

Promoting research on retirement, disability, and Social Security policy

\title{
How Reliant are Older Americans on State and Local Government Pensions?
}

Philip Armour, Michael D. Hurd, and Susann Rohwedder

MRDRC WP 2019-399

UM19-07 


\section{How Reliant are Older Americans on State and Local Government Pensions?}

Philip Armour

RAND
Michael D. Hurd

RAND

\author{
Susann Rohwedder \\ RAND
}

September 2019

Michigan Retirement and Disability Research Center, University of Michigan, P.O. Box 1248. Ann Arbor, MI 48104, mrdrc.isr.umich.edu, (734) 615-0422

\section{Acknowledgements}

The research reported herein was performed pursuant to a grant from the U.S. Social Security Administration (SSA) funded as part of the Retirement Research Consortium through the University of Michigan Retirement Research Center Award RDR18000002. The opinions and conclusions expressed are solely those of the author(s) and do not represent the opinions or policy of SSA or any agency of the federal government. Neither the United States government nor any agency thereof, nor any of their employees, makes any warranty, express or implied, or assumes any legal liability or responsibility for the accuracy, completeness, or usefulness of the contents of this report. Reference herein to any specific commercial product, process or service by trade name, trademark, manufacturer, or otherwise does not necessarily constitute or imply endorsement, recommendation or favoring by the United States government or any agency thereof.

\section{Regents of the University of Michigan}

Jordan B. Acker; Huntington Woods; Michael J. Behm, Grand Blanc; Mark J. Bernstein, Ann Arbor; Paul W. Brown, Ann Arbor; Shauna Ryder Diggs, Grosse Pointe; Denise llitch, Bingham Farms; Ron Weiser, Ann Arbor; Katherine E. White, Ann Arbor; Mark S. Schlissel, ex officio 


\title{
How Reliant are Older Americans on State and Local Government Pensions?
}

\begin{abstract}
State and local government pension plans cover about 19.5 million participants, and many participants are heavily reliant on these pensions for retirement income. Most of these plans, however, are underfunded. Based on data from the Health and Retirement Study, we examined the lifetime work histories of those observed at ages 67 to 72 in 2004, 2008, or 2014. Seventyseven percent of single persons and 61 percent of couple households had never worked for state or local (S\&L) government. Among those single and couple households who did work for S\&L government, we found that they have on average more years of education and more economic resources. Among currently retired and near-retirement households, we compared economic preparation for retirement according to their lifetime employment in the S\&L sector, and we examined how economic preparation would be affected if pension benefits were cut. Based on stochastic simulations, which account for uncertainty about length of life and out-ofpocket medical expenditures, we found that economic preparation for retirement among those with S\&L government work histories would only be modestly reduced if their pension income were cut. Under a 50 percent cut to all pension income of households with any S\&L sector work, only an additional three to four percent of these households would no longer be prepared for retirement. The change is modest because households with S\&L employment have better preparation than other households; some of the cuts are paid for by reduced taxes; and the affected households will bequeath less.
\end{abstract}

\section{Citation}

Armour, Philip, Michael D. Hurd, and Susann Rohwedder. 2019. "How Reliant are Older Americans on State and Local Government Pensions?" Ann Arbor, MI. University of Michigan Retirement and Disability Research Center (MRDRC) Working Paper; MRDRC WP 2019-399. https://mrdrc.isr.umich.edu/publications/papers/pdf/wp399.pdf 


\section{Background and overview}

State and local government pension plans cover approximately 19.5 million participants, including active employees, former employees who have not yet started collecting benefits, and those currently receiving benefits. Twenty-eight percent of state and local government workers are not covered by Social Security (CRS 2011). Public sector workers are heavily dependent on these pensions: Nearly half of income for households with strong public sector work experience comes from pensions or annuities, and the fraction of income from Social Security is lower the more public sector work experience a household has. ${ }^{1}$ However, depending on modeling assumptions, state and local (S\&L) government pensions are underfunded by $\$ 800$ billion to $\$ 4$ trillion, with a fifth of these plans underfunded by at least $40 \%$ (CSLGE 2016). Any cuts to these benefits have direct consequences on Social Security through the Windfall Elimination Provision, the Government Pension Offset, and eligibility for Supplemental Security Income, as well as a broader impact on old-age income support.

Given the large number of S\&L government employees who rely on public pensions for their retirement income, there is considerable concern about the repercussions should some of these pension plans default. What fraction of the population would be affected? How would the effects be distributed among both individuals and households? How would any resulting benefit cuts affect households' economic preparation for retirement? Little is known about these particular questions or,

\footnotetext{
${ }^{1}$ Hurd, Michael D., "Financial Situation After Retirement of Those Who Worked in the Public Sector," presentation at the NBER Workshop, "Implications of the Changes and Challenges Facing State Retirement Systems," April 17, 2018, Washington D.C.
} 
more generally, about government workers' reliance on their pensions in the context of their overall household wealth, as well as how this reliance differs between current retirees and those nearing retirement.

To address these gaps in our understanding, this paper provides estimates of reliance on S\&L government pensions by older Americans, taking into account the full inventory of household assets they can draw from. We assess their economic preparation for retirement in a simulation model, evaluating the impact of reductions in state and local pension payments on adequacy of retirement resources. Because of changing employment in the public sector relative to the private sector and changing prevalence of defined benefit pensions, we report a cohort analysis that aims to find trends in economic resources among workers approaching retirement and in their exposure to state and local government pensions.

Specifically, using data from the Health and Retirement Study (HRS), we

1. measure lifetime S\&L public sector employment among HRS respondents who are in their late 60 s and early 70 s;

2. find how economic resources vary as a function of years of S\&L employment;

3. assess economic preparation for retirement among the recently retired, comparing preparation among those with and without S\&L government pension entitlement;

4. simulate how cuts to S\&L pension entitlements would affect economic adequacy. 


\section{Data and Methods}

We use data from the Health and Retirement Study (HRS), a panel survey of Americans at least 51 years of age conducted every two years since 1992. At induction, the HRS asks respondents about current and prior lifetime work, including durations of jobs, whether the jobs were in the public sector, and whether any public sector job was in state or local government. In the HRS longitudinal interviews, workers are asked similar questions about current employment. From these data, we construct lifetime employment histories including lifetime employment in S\&L government. The histories show for each individual the total number of years worked and the number of years worked in S\&L government, the federal government, and the private sector.

Because pensions and Social Security are unlikely to be paid while individuals are still working, estimation of their eventual reliance on pensions and Social Security may be inaccurate due to reporting error. To address this issue, we study reliance among HRS retirees for whom pensions and Social Security are likely to be in pay status so that they can be observed with little error. Specifically, we examine cohorts who were 67 to 72 years old in the 2004, 2008, and 2014 iterations of the survey.

The HRS directly asks about income from pensions and income from Social Security, but it does not connect income from those sources with the work years that produced the income. For example, someone reporting pension income with a history of work in both the S\&L sector and the private sector could have the income from an S\&L pension, from a private defined benefit pension, or from both. We have developed an estimation method based on years of service in each of the three sectors to estimate the fraction of reported pension income that flows from the S\&L sector. 
We describe the economic status of each cohort and how S\&L government pension reliance varies with lifetime exposure to public sector employment. Because we have the work histories of both spouses in the case of couples, we can connect the pension entitlements of each to describe the household's dependence on S\&L pensions.

To assess overall economic retirement preparation of those with varying degrees of reliance on S\&L pensions, we use the simulation model developed by Hurd and Rohwedder (2012). Grounded in the life-cycle hypothesis, the model uses total economic resources and total spending as observed in the HRS for each household at or around age 66 to simulate the trajectories of spending and wealth until death. Based on many stochastic simulations, total economic resources of a household are deemed adequate if, with minor adjustments to spending, the probability of running out of wealth at the end of life is less than $5 \%$.

We run several sets of simulations, varying the assumptions about what fraction of S\&L pension benefits will be paid. We examine the impact of the different scenarios on economic preparation for retirement overall and across demographic subgroups.

\section{Analytic Sample}

We examine the work histories of three different cohorts. Specifically, we examine from the

- 2004 wave, respondents born between 1932 and 1937, who were then 67 to 72 years old; 
- 2008 wave, respondents born between 1936 and 1941, who were then 67 to 72 years old (excluding those born in 1936 or 1937 who are included in the 2004 wave);

- 2014 wave, respondents born between 1942 and 1947, who were then 67 to 72 years old.

We analyze respondents 67 to 72 years old to obtain a complete picture of their work history. At these ages, the great majority of respondents have completed their work history and are being paid any pensions to which they are entitled. More details of the selection criteria are given in the Appendix.

Table 1 shows descriptive statistics of our analytic sample of 5,277 respondents. The respondents' average age at the time of the survey was 70.2 . Half of the respondents were married, and about one in four were widowed. Nearly two-thirds were female, and most had no more than a high school education. Respondents had worked 32.8 years on average, with an average of 4.9 years in S\&L government and 1.2 years in federal government. We also note the median years of government work was 0 , meaning most respondents did not work for government (and that our averages are, of course, calculated across all respondents).

In presenting our analyses below, we focus on the status of the individual among single persons, and on the status of the household among married or partnered persons. 


\section{Results}

\section{Reliance on state and local pensions}

We first describe the distribution in the population of past work for S\&L governments, stratifying by the number of service years. This is one of the main determinants of entitlements to state or local pensions. In a couple household, the respondent, the spouse, or both may have worked for state or local government. Because our analysis is on the household level, for couple households we use the number of years for the spouse with the greatest number of years worked for S\&L government.

Table 2 shows our results for single persons 67 to 72 years old. Among singles, $76.7 \%$ had no S\&L government employment. At the opposite extreme, $5.8 \%$ had at least 20 years of such employment. Not surprisingly, the total years employed, shown in the right-most column, also increases with the number of years in the S\&L sector, because any time in S\&L sector employment will automatically increase total employment as well. The average number of years employed in the federal sector, shown in the second column from the right, also increases with the total number of years of S\&L sector employment.

Table 3 shows lifetime years of service for S\&L government for couple households, classified by years of S\&L service of the spouse with the longest period of work for state-and-local government. In $60.8 \%$ of couple households, neither spouse had any employment in the S\&L sector. Such couples worked a combined 66.9 years, double the 31.7 years of singles with no S\&L sector employment. At the opposite 
extreme, $11.8 \%$ of couples had a member who worked at least 20 years in the S\&L sector.

Table 4 shows the joint distribution of employment years in the S\&L sector for both spouses in couple households. For example, in the top left cell, it shows, as noted on Table 3, that in $60.8 \%$ of couple households neither spouse had any S\&L sector employment, while also showing, in the cell below, that $9.3 \%$ of couples had a wife who worked in the S\&L sector for less than 10 years and a husband who did not work in it at all. Altogether, Table 4 shows that $26 \%$ of wives in couple households had some S\&L sector employment, as did $22 \%$ of husbands. It also shows correlation in S\&L sector employment for couples. For example, only $2 \%$ of wives overall had at least 30 years of S\&L sector employment. Among couples whose husbands had at least 30 years of $S \& L$ sector employment, however, $12 \%$ of wives did so as well. This correlation makes couple households more vulnerable to failures of state-and-local government pensions.

Table 5 shows the years of education as a function of S\&L employment. Differences in educational attainment by years of work in the $S \& L$ sector is greatest for singles. Among singles, those with no S\&L sector have an average of 12.04 years of educational attainment, while those with at least 30 years have 14.56 years of educational attainment, a difference of 2.52 years. Comparable differences for husbands and wives in couple households are smaller but still substantial.

Table 6 shows variation in economic resources by S\&L sector employment. Because those with longer periods of S\&L government employment have worked more years and have greater educational attainment, we would expect a positive relationship between economic resources and S\&L sector employment, as we generally find. For 
both single and couple households, median wealth (which accounts for all assets net of debt, including housing) is greater for those with more S\&L sector employment. Among single persons with 30 or more years of S\&L sector employment, for example, median wealth is about three times as large as it is among those with no such employment. The income differences are also substantial. Variation in wealth and income is somewhat less for couples, as would be expected because the spouse of someone with many years in S\&L government employment is unlikely also to have many years in such employment.

Table 7 shows that the proportion of singles and of couples with pension income also increases sharply with the length of S\&L sector employment. Income from pensions (averaged over both those with pension income and those without) increases even more sharply. There are three likely causes for this sharper increase in income. First, as the table shows, the proportion of workers with pension income increases with years worked for S\&L government. Second, as shown earlier, those with more years of S\&L government employment are more likely to have more education, and those with more education are likely to have more income. Third, defined benefit pension income is approximately quadratic, because benefits depend on years of service and on a multiplicative factor that, itself, depends on years of service.

Table 8 shows Social Security income by years of work in S\&L government. Among single persons, Social Security income by years of service in S\&L government is relatively flat. Among couples with at least one spouse who worked in S\&L government, Social Security benefits are lower for those with more years in the S\&L sector. This 
likely reflects the fact that some workers in the S\&L sector do not contribute to Social Security.

Table 9 combines the information from Tables 7 and 8 to show the variation in the proportion of total income from pensions and from Social Security. For both single persons and for couples, the relative importance of pension income increases with length of employment in the S\&L sector and the relative importance of Social Security income decreases. The differences are substantial. For example, among single persons with no S\&L sector employment only $12.2 \%$ of income comes from pensions, whereas among those with 30 or more years of service $41.6 \%$ comes from pensions.

Because of the systematic variation by personal characteristics and by years of employment in S\&L government, we estimate regression models to better assess the importance of pension income.

Table 10 shows for single persons the regression coefficients, standard errors, and an indicator for statistical significance for three outcomes: whether the respondent has any pension income (linear probability model); the proportion of income from pensions (including those with zero pension income); and, among those with pension income, the logarithm of pension income.

The model shows older singles (among the 67 to 72 cohort in our analysis) are more likely to have pension income. This may be a result of differential mortality, with the more well-to-do likely to live longer and have pension income. Among cohorts, there is a significant difference in the logarithm of pension income, with mean pension income increasing from 2004 to 2008 and from 2008 to 2014 . 
The table also shows large differences by education: Those with less than high school education are less likely to have pensions and to have a smaller proportion of income from pensions, while college graduates are more likely to have them and to have a larger proportion of income from them. Widowed respondents are more likely than the never married or divorced to have pension income, which may be from a deceased spouse. Respondents who worked more years across all jobs are more likely to have pension income, but the effect is not large. The effects of employment length in the S\&L sector particularly, by contrast, have strong effects on any pension income receipt, the proportion of income derived from pensions, and the logarithm of pension income.

The column showing coefficients for the pension income logarithm has some further results worth noting. Conditional on having pension income, men receive, on average, $29 \%$ more pension income than women do. Similarly, among those with pension income, those with at least a college education receive considerably more than others. Because of the correlation between S\&L employment and federal government employment, we included years of service in the latter. Those with pension income and at least 20 years of work for the Federal government receive more pension income than those with similar experience in S\&L employment.

Table 11 shows similar results for couple households, but now the results pertain to the household, although the explanatory variables pertain to individuals. Many of the patterns are the same as for single persons. But we do not find any significant cohort differences as we do find for single persons. For example, the logarithm of pension income reported by 67- to 72-year-old respondents was roughly the same across the 
2004, 2008, and 2014 HRS waves. The husband's work experience is a more important determinant of whether a couple household receives a pension. But we see that the work experiences of both spouses matter. The effect of 20 to 30 years of experience in S\&L government by the husband is 0.498 and 0.511 by the wife.

\section{Economic preparation for retirement}

We used the simulation model developed by Hurd and Rohwedder (2012) to assess overall economic retirement preparation of those with varying degrees of reliance on S\&L pensions and compared the results to those for the rest of the population. Grounded in the life-cycle hypothesis, the model uses total economic resources and total spending as observed in the HRS for each household at or around age 66 to simulate the trajectories of spending and wealth until death. Based on many stochastic simulations where the random outcome is the date of death, total household economic resources are deemed adequate if, with minor adjustments to spending, the probability of running out of wealth at the end of life is less than $5 \%$.

Critical data items for the model are consumption and the change in consumption. We obtain those data from the Consumption and Activities Mail Survey (CAMS), which is administered to about 5,000 HRS households who are asked about their total annual spending (Hurd and Rohwedder, 2015). Begun in 2001, the CAMS, like the HRS, is conducted every two years. We link households in our sample to those that were CAMS households to find consumption. Then, using observed consumption changes in the CAMS panel, we simulate the spending path of each household, taking into account differential mortality, stochastic health care spending, and the economic constraints of the household (Hurd and Rohwedder 2012). 
Table 12 shows the initial conditions for the simulations. We found 776 single persons who satisfied the conditions for the simulations, that is, they were in our analytic sample of respondents 67 to 72 years old and were also administered the CAMS around the time they were 66 . Of these, 570 had no history of working in S\&L government, and 206 did have a history. Those who had worked in the S\&L sector had higher wealth and retirement income (the sum of Social Security income, pension income, and annuity income). Their initial consumption was also higher, reflecting their greater economic resources.

We also found 1,122 couple households that satisfied our age criteria and were part of the CAMS sample. Among these, 459 had a least one person with S\&L sector employment, and in 104 households both spouses had such experience. The 459 households with at least one spouse with S\&L sector employment had more wealth, more retirement income, a greater fraction of the retirement income from pension income, and more initial consumption. The 104 households where both spouses had S\&L sector employment had still higher retirement income: about $\$ 63,000$ compared to about $\$ 50,000$ for the 355 households in which only one spouse had S\&L sector employment. They also had about the same median wealth but lower mean wealth than the 355 households in which only one spouse had S\&L sector employment. Their initial consumption was about $\$ 4,000$ higher than for households with only one spouse with S\&L sector employment.

We ran several sets of simulations, varying the assumptions about what percentage of public pension benefits will be paid $(100 \%, 70 \%$, and $50 \%)$. The source of pension income in the HRS cannot directly be identified, so we applied these cuts to 
the total pension income of those with S\&L sector employment. ${ }^{2}$ We examined the impact of the different scenarios on economic preparation for retirement overall and across demographic subgroups.

Table 13 shows our scenarios for single respondents and Table 14 for couple households. The columns show scenarios for whether respondents had not had S\&L sector employment or, if they had such employment, whether their pensions are not cut or cut 30 or $50 \%$ (that is, whether they will receive $100 \%, 70 \%$, or $50 \%$ of their pension income). The first three rows show their resources: initial wealth, present value of earnings not yet recorded at baseline, and present value of retirement income (monetary values in thousands of 2014 dollars). The next two lines show uses for their resources: mean present value for the taxes they will pay and the consumption they will have, with the remainder being bequests (or wealth remaining at death), shown at the bottom of the table. Lifetime budget constraints must be satisfied, that is, total inflows of money (including initial wealth) must equal total outflows (including bequests). The next line shows percent with positive wealth at death, who, by having remaining resources, may be considered adequately prepared for retirement. The last two lines show the mean and median values of remaining excess wealth at death (i.e., bequests).

Table 13 shows that, on average, single respondents with no S\&L government employment in their career had about $\$ 500,000$ in resources at retirement including the present value of retirement income (Social Security, pensions, and annuities). A little more than half of this was in mean initial wealth, but nearly half was in expected

${ }^{2}$ Our estimates of the effects of the cuts will be biased toward larger effects because some S\&L workers may have retirement income from private rather than public pensions, which, of course, would not actually be affected. 
retirement income. Most of these resources were used to finance consumption, with about $8 \%$ of their resources going to taxes and the remainder, or $34 \%$ of the total, going to bequests. In more than $95 \%$ of our simulations, $66 \%$ of these single respondents died with positive wealth, indicating they were adequately prepared for retirement.

For singles with S\&L sector employment, we report results from three types of simulations: pension levels as reported, pension levels cut by $30 \%$, and levels cut by $50 \%$. These do not reduce initial wealth or present value of earnings. The present value of retirement income decreases but not by a full 30 or $50 \%$ because some retirement income comes from Social Security and annuities which are unaffected.

Singles who undergo a $50 \%$ cut in pension income see the present value of their retirement income decrease about $\$ 68,200$, or $21 \%$, relative to singles who have no cut to their pension income. In principle, average consumption in the population would be reduced due to more individuals running out of wealth and being forced to reduce consumption. But in very few simulations did this happen so that average population consumption was unchanged to the accuracy reported in the table. Under the $50 \%$ cut, individuals pay about $\$ 20,800$, or $28 \%$, less in taxes, and their bequests decreased by $\$ 47,400$, or $18 \%$. Altogether, $68.9 \%$ of singles whose pensions are cut $50 \%$ have wealth at death with high probability, and so under our definition they are still considered to be adequately prepared for retirement. Among those with no pension cuts, $73.1 \%$ of singles had positive wealth at death in $95 \%$ of our simulations.

Table 14 shows the simulation results for couples. As is evident for single persons, couples with S\&L government work experience have greater wealth, earnings, and retirement income, and a higher present value of consumption. Among those 
without S\&L sector employment, nearly half of their resources go to consumption, a little more than $11 \%$ go to taxes, and the remainder (about $40 \%$ ) goes to bequests. The allocations are somewhat different for those with S\&L sector employment: a greater fraction is paid in taxes, and a smaller fraction consumed. Because those with S\&L sector employment have more economic resources, they are marginally better prepared for retirement: $89.9 \%$ versus $88.5 \%$.

Couples who have their pension income reduced by $50 \%$ would see their retirement income decrease by $16 \%$. Their taxes would also be reduced by $15 \%$, while the value of their bequests would diminish by $10 \%$. Overall, the percent having positive wealth at death with high probability—our indicator for adequate economic preparation for retirement—would decrease 3.0 percentage points.

Table 15 presents our analysis of economic preparation at retirement by cohort and by work experience in S\&L government. It uses, as Tables 13 and $14 \mathrm{did}$, the estimated percentage of HRS respondents who will have positive wealth at death with a probability of $95 \%$ or greater as the indicator for adequate preparation for retirement.

Among singles in our sample of the $2004 \mathrm{HRS}$, economic preparation for retirement was more frequent than among comparable singles in either 2008 or 2014 . Those with work experience in S\&L government were better prepared than others by 10.9 percentage points. By 2008 , overall preparation for retirement decreased 6.8 percentage points, likely because of the decrease in housing values that began before 2008 , as well as the decline in the stock market that began in July 2008 . The advantage of those with S\&L experience over those without S\&L experience diminished 
to 5.7 percentage points, possibly because the former held more assets and so were at greater risk from the declines in the housing and stock markets.

By 2014, there was some recovery in both housing and stock market values. As a result, overall preparation for retirement increased somewhat for all singles, and the advantage that S\&L sector workers had increased to 6.5 percentage points.

For couples, the patterns are different. Over all cohorts, 89 percent of couples were adequately prepared for retirement. In the 2004 cohort, those with no work in S\&L government actually had better financial preparation for retirement than those who did. In 2008 and 2014, those with S\&L sector experience had slightly better preparation for retirement.

Overall, there does appear to have been a slight worsening in economic preparation for retirement between 2004 and 2014 among persons 67 to 72 yearsold. For singles, there was a decrease of 5.0 percentage points, and for couples there was a decrease of 4.5 percentage points. This is consistent with other indicators, such as indicators for health, that have shown a worsening of conditions for successive cohorts of older Americans (Hudomiet, Hurd, and Rohwedder 2019).

\section{Conclusions}

Overall, our research finds that, among persons 67 to 72 years old in the 2004, 2008, and 2014 HRS, those who had worked in S\&L government at some time during their work lives reached retirement age with more economic resources than those who had not. Partly this results from a positive relationship between years worked in the S\&L sector and more years worked in all jobs. Nevertheless, the differences in economic resources were greater than service years would imply. For example, among singles, 
those with some but less than 10 years of service in the S\&L sector had median wealth of $\$ 131,791$, and mean income of $\$ 43,149$, as shown in Table 6 . Those with 20 to 30 years of S\&L sector experience, however, had median wealth of $\$ 210,983$ and mean income of $\$ 53,345$. This suggests that those with more experience in the S\&L sector had higher annual earnings as well as working more years.

While the majority of those with S\&L employment received pension income, most are not heavily reliant on pension income. Those with less than 20 years of service in the S\&L sector rely on pensions for less than one-fourth of their income. While those with at least 20 years of service in the S\&L sector rely on pensions for more than onethird of their income, these highly dependent populations are not large, comprising $5.8 \%$ of singles and $11.8 \%$ of couples.

Judging economic preparation for retirement involves comparing economic resources to consumption. Both singles and couples in their late 60s spend on average approximately $\$ 7,000$ more per year than they receive in income. Although this implies that they will need to dissave, the required wealth to maintain consumption is not large relative to the mean. But the median wealth of single persons was just $\$ 81,000$, including illiquid housing wealth. The large difference between mean and median indicates that wealth is highly skewed, so that mean values do not represent well the situation of many people. Indeed, we found that just $68.2 \%$ of single persons were adequately prepared for retirement in our overall sample. Among couples, $89.1 \%$ were adequately prepared.

Our findings on the effects of S\&L government pension cuts on retirement income have a significant caveat: We cannot, as noted, separate such pension income 
from other pension income. So our analyses should be considered upper bounds of the effects. We do find that small fractions of the population-those with at least 20 years in the S\&L sector, who comprise $6 \%$ of singles and $12 \%$ of couples-do have major resources in pension income. As a result (and as Tables 13 and 14 show), among pension recipients, a $50 \%$ cut in pensions would result in a 4.2 percentage point reduction in adequate preparation for retirement among singles and a 3.0 percentage point reduction among couples.

Cohort effects are relatively small. While our data show some reduction in adequate preparation for retirement between 2004 and 2008, this reduction was small and partly reversed itself between 2008 and 2014 .

In sum, we find that even if S\&L government pensions are cut by $50 \%$, the effects on economic retirement preparation, even among those who worked in S\&L government, are likely to be modest. 


\section{References}

Center for State and Local Government Excellence, 2016, "The Funding of State and Local Pensions: 2015-2020," Issue Brief.

Congressional Research Service, 2011, "Social Security: Mandatory Coverage of New State and Local Government Employees," 7-5700.

Hudomiet, Péter, Michael D. Hurd and Susann Rohwedder, 2019, "Trends in Health and Mortality Inequalities in the U.S., typescript.

Hurd, Michael D. and Susann Rohwedder, 2012, "Economic Preparation for Retirement," in D. Wise (ed.) Investigations in the Economics of Aging, Chicago: University of Chicago Press.

Hurd, Michael D. and Susann Rohwedder, 2015, "Wealth Dynamics and Active Saving at Older Ages," in Improving the Measurement of Consumer Expenditures, eds. Christopher Carroll, Thomas Crossley and John Sabelhaus, University of Chicago Press, 2015, pages $388-413$. 


\section{Tables}

Table 1. Descriptive statistics for pooled cohort sample

\begin{tabular}{lccc}
\hline & $\mathbf{N}$ & Mean & Median \\
\hline HRS cohort & 5,277 & 0.733 & 1.000 \\
War Babies (WB) cohort & 5,277 & 0.267 & 0.000 \\
Year 2004 & 5,277 & 0.222 & 0.000 \\
Year 2008 & 5,277 & 0.511 & 1.000 \\
Year 2014 & 5,277 & 0.267 & 0.000 \\
Married & 5,277 & 0.500 & 1.000 \\
never married & 5,277 & 0.044 & 0.000 \\
Divorcesep & 5,277 & 0.184 & 0.000 \\
Widowed & 5,277 & 0.271 & 0.000 \\
Male & 5,277 & 0.356 & 0.000 \\
Age & 5,277 & 70.209 & 70.000 \\
Less than high school & 5,277 & 0.235 & 0.000 \\
High school & 5,277 & 0.370 & 0.000 \\
Some college & 5,277 & 0.200 & 0.000 \\
College or more & 5,277 & 0.193 & 0.000 \\
Years in S\&L employment & 5,277 & 4.880 & 0.000 \\
Years in Federal employment & 5,277 & 1.211 & 0.000 \\
Years worked & 5,277 & 32.837 & 39.000 \\
Wealth & 5,277 & 561,971 & 199,397 \\
Income & 5,277 & 61,881 & 37,662 \\
Fraction with pension income & 5,277 & 0.387 & 0.000 \\
Pension income & & & \\
(unconditional) & 5,277 & 7,644 & 0.000 \\
SS income & 5,277 & 12,804 & 12,937 \\
\hline
\end{tabular}


Table 2. Lifetime years employed, single persons ages 67 to 72 . Weighted

\begin{tabular}{lcccc}
\hline Years in S\&L sector & $\mathbf{N}$ & Distribution & Years in Fed sector & Years employed \\
\hline None & 1,982 & 76.7 & 0.9 & 31.7 \\
$\mathbf{0}-<\mathbf{1 0}$ & 315 & 12.2 & 1.6 & 37.3 \\
$\mathbf{1 0 - < 2 0}$ & 138 & 5.3 & 1.9 & 40 \\
$\mathbf{2 0 - < 3 0}$ & 87 & 3.4 & 3.1 & 37.2 \\
$\mathbf{3 0 +}$ & 62 & 2.4 & 4.5 & 41.7 \\
Total & 2,584 & 100 & 1.2 & 33.3 \\
\hline
\end{tabular}

Table 3. Lifetime years employed, married persons ages 67 to 72 . Total both spouses classified by years in S\&L sector of longest serving spouse. Weighted

\begin{tabular}{lcccc}
\hline Years in S\&L sector & $\mathbf{N}$ & Distribution & Years in Fed sector & Years employed \\
\hline None & 1,596 & 60.8 & 2 & 66.9 \\
$\mathbf{0}-<\mathbf{1 0}$ & 475 & 18.1 & 3.3 & 73.8 \\
$\mathbf{1 0 - < 2 0}$ & 244 & 9.3 & 5 & 76 \\
$\mathbf{2 0 -}<\mathbf{3 0}$ & 170 & 6.5 & 3.5 & 74.6 \\
$\mathbf{3 0 +}$ & 140 & 5.3 & 7.2 & 79.3 \\
Total & 2,625 & 100 & 2.9 & 70.1 \\
\hline
\end{tabular}

Table 4. Relationship between S\&L service of spouses

\begin{tabular}{lcccccc}
\hline & \multicolumn{7}{c}{ Husband's Years of S\&L Service } \\
\hline Wife's Years of S\&L Service & None & $\mathbf{0}-<\mathbf{1 0}$ & $\mathbf{1 0}-<\mathbf{2 0}$ & $\mathbf{2 0}-<\mathbf{3 0}$ & $\mathbf{3 0 +}$ & Total \\
\hline None & 60.82 & 6.52 & 2.66 & 2.28 & 1.48 & 73.76 \\
$\mathbf{0}-<\mathbf{1 0}$ & 9.26 & 2.3 & 0.63 & 0.65 & 0.79 & 13.63 \\
$\mathbf{1 0 - < 2 0}$ & 4.9 & 0.64 & 0.45 & 0.14 & 0.46 & 6.59 \\
$\mathbf{2 0 - < 3 0}$ & 2.13 & 0.35 & 0.37 & 0.54 & 0.47 & 3.87 \\
$\mathbf{3 0 +}$ & 0.98 & 0.21 & 0.13 & 0.38 & 0.44 & 2.14 \\
Total & $\mathbf{7 8 . 0 9}$ & 10.03 & 4.24 & 3.99 & 3.65 & 100 \\
\hline
\end{tabular}


Table 5. Years of education and years of service in S\&L. In the case of couples classified by spouse with greatest years of S\&L service

\begin{tabular}{lccc}
\hline $\begin{array}{l}\text { Years in S\&L } \\
\text { sector }\end{array}$ & Singles & Couples Husband & Couples Wife \\
\hline None & 12.04 & 12.40 & 12.20 \\
$\mathbf{0}-<\mathbf{1 0}$ & 13.28 & 13.65 & 13.65 \\
$\mathbf{1 0 - < \mathbf { 2 0 }}$ & 13.89 & 13.68 & 13.68 \\
$\mathbf{2 0}-<\mathbf{3 0}$ & 13.87 & 13.69 & 13.91 \\
$\mathbf{3 0 +}$ & 14.56 & 14.48 & 14.35 \\
Total & 12.41 & 12.94 & 12.83 \\
\hline
\end{tabular}

Table 6. Median wealth, Mean income and YoS in S\&L. Weighted

\begin{tabular}{lcccc}
\hline & \multicolumn{2}{c}{ Singles } & \multicolumn{2}{c}{ Couples } \\
\hline Years in S\&L sector & $\begin{array}{c}\text { Median } \\
\text { wealth }\end{array}$ & $\begin{array}{c}\text { Mean } \\
\text { income }\end{array}$ & $\begin{array}{c}\text { Median } \\
\text { wealth }\end{array}$ & $\begin{array}{c}\text { Mean } \\
\text { income }\end{array}$ \\
\hline None & 98,369 & 43,184 & 334,281 & 82,717 \\
$\mathbf{0}-<\mathbf{1 0}$ & 131,791 & 43,149 & 503,840 & 97,832 \\
$\mathbf{1 0 - < 2 0}$ & 233,355 & 63,000 & 398,794 & 104,380 \\
$\mathbf{2 0}-<\mathbf{3 0}$ & 210,983 & 53,345 & 604,141 & 99,263 \\
$\mathbf{3 0 +}$ & 318,742 & 104,972 & 688,265 & 124,452 \\
Total & 118,442 & 46,060 & 402,962 & 90,763 \\
\hline
\end{tabular}

Note: Income and wealth in $2014 \$$

Table 7. Frequency of pension income and mean pension income. Weighted

\begin{tabular}{lcccc}
\hline & \multicolumn{2}{c}{ Singles } & \multicolumn{2}{c}{ Couples } \\
\hline $\begin{array}{l}\text { Years in S\&L } \\
\text { sector }\end{array}$ & Frequency & $\begin{array}{c}\text { mean } \\
\text { income }\end{array}$ & frequency & $\begin{array}{c}\text { mean } \\
\text { income }\end{array}$ \\
\hline None & 0.361 & 5,945 & 0.509 & 11,875 \\
$\mathbf{0}-<\mathbf{1 0}$ & 0.407 & 6,462 & 0.636 & 16,201 \\
$\mathbf{1 0 - < 2 0}$ & 0.679 & 13,984 & 0.646 & 17,442 \\
$\mathbf{2 0 - < 3 0}$ & 0.757 & 20,571 & 0.803 & 33,775 \\
$\mathbf{3 0 +}$ & 0.745 & 26,004 & 0.753 & 41,988 \\
Total & 0.406 & 7,410 & 0.577 & 16,201 \\
\hline
\end{tabular}

Note: Income in $2014 \$$ 
Table 8. Mean Social Security income. Weighted

\begin{tabular}{lccc}
\hline & Singles & Couples & Total \\
\hline None & 13,872 & 26847 & 19,576 \\
$\mathbf{0}-<\mathbf{1 0}$ & 13,857 & 28,117 & 22,340 \\
$\mathbf{1 0}-<\mathbf{2 0}$ & 13,262 & 26,750 & 21,800 \\
$\mathbf{2 0}-<\mathbf{3 0}$ & 12,075 & 25,022 & 20,561 \\
$\mathbf{3 0 +}$ & 13,406 & 22,118 & 19,399 \\
Total & 13,766 & 26,697 & 20,198 \\
\hline
\end{tabular}

Note: Income in $2014 \$$

Table 9. Proportion of income from pensions and from Social Security income.

\begin{tabular}{lcccc}
\hline & \multicolumn{2}{c}{ From pensions } & \multicolumn{2}{c}{ From Social Security } \\
\hline $\begin{array}{l}\text { Years in S\&L } \\
\text { sector }\end{array}$ & Singles & Couples & Singles & Couples \\
\hline None & 0.122 & 0.150 & 0.583 & 0.534 \\
$\mathbf{0 - < 1 0}$ & 0.145 & 0.201 & 0.554 & 0.469 \\
$\mathbf{1 0 - < 2 0}$ & 0.245 & 0.195 & 0.351 & 0.404 \\
$\mathbf{2 0 - < 3 0}$ & 0.422 & 0.342 & 0.331 & 0.382 \\
$\mathbf{3 0 +}$ & 0.416 & 0.357 & 0.266 & 0.332 \\
Total & 0.148 & 0.187 & 0.551 & 0.489 \\
\hline
\end{tabular}


Table 10. Singles Regressions

(1)

(2)

(3)

Male
R age
HRS year 2004
HRS year 2008
Less than HS (educ reference HS)
Some College
College+
Never married (reference widowed)
Divorced or Separated
Years worked all jobs

S\&L $0-<10$ yrs (reference zero)

$S \& L 10-<20$ yrs

$S \& L 20-<30$ yrs

S\&L 30+ yrs

FED $0-<10$ yrs (reference zero)

FED $10-<20$ yrs

FED $20-<30$ yrs

FED $30+$ yrs

Constant

Observations

R-squared

Standard errors in parentheses

${ }^{*} p<0.1$
Whether any pension income

$$
0.014
$$

$(0.022)$

$0.013^{* *}$

$(0.006)$

0.021

$(0.026)$

$-0.034$

$(0.022)$

$-0.161^{* * *}$

$(0.023)$

$0.047^{*}$

$(0.025)$

$0.084^{* * *}$

$(0.029)$

$-0.091^{\text {*** }}$

$(0.033)$

$-0.079^{\star \star \star}$

$(0.020)$

$0.002^{* * *}$

$(0.000)$

0.018

(0.029)

$0.218^{\star \star *}$

$(0.041)$

$0.311^{\star * *}$

$(0.045)$

$0.290^{* * *}$

$(0.056)$

0.033

$(0.043)$

$0.215^{\star * *}$

(0.071)

0.116

(0.088)

0.053

$(0.100)$

$-0.520$

(0.393)

2637

0.113

Proportion of income from pensions

$$
\begin{gathered}
0.022^{\star *} \\
(0.011) \\
0.006^{* *} \\
(0.003) \\
0.002 \\
(0.012) \\
-0.021^{* *} \\
(0.011) \\
-0.071^{\star * *} \\
(0.011) \\
0.005 \\
(0.012) \\
0.047^{\star * *} \\
(0.014) \\
-0.020 \\
(0.016) \\
-0.014 \\
(0.010) \\
-0.000 \\
(0.000) \\
0.006 \\
(0.014) \\
0.103^{\star * *} \\
(0.020) \\
0.241^{* * *} \\
(0.022) \\
0.268^{\star * *} \\
(0.027) \\
0.021
\end{gathered}
$$

0.021

$(0.021)$

$0.082^{* *}$

$(0.034)$

$0.272^{* * *}$

(0.042)

$0.271^{\text {** }}$

(0.048)

$-0.264$

(0.189)

2637

0.162

${ }^{* *} p<0.05$

${ }^{* * *} p<0.01 "$
Log pension income (conditional)

$0.288^{\star * *}$

(0.078)

$-0.021$

(0.020)

$-0.211^{* \star}$

(0.089)

$-0.157^{* *}$

(0.079)

$-0.432^{\star * *}$

(0.095)

0.127

(0.085)

$0.691^{* * *}$

(0.093)

0.033

$(0.123)$

0.097

(0.072)

$-0.001$

$(0.002)$

$-0.046$

(0.105)

$0.266^{* *}$

(0.117)

$0.691^{\text {** }}$

(0.121)

$0.815^{\star \star *}$

(0.148)

$-0.116$

(0.136)

0.192

(0.195)

$1.252^{\star * *}$

(0.263)

$0.921^{* * *}$

$(0.296)$

$10.499^{* * *}$ (1.424)

993

0.245 


\begin{tabular}{|c|c|c|c|}
\hline & $\begin{array}{c}\text { Whether any } \\
\text { pension income }\end{array}$ & $\begin{array}{l}\text { Proportion of } \\
\text { income from } \\
\text { pensions }\end{array}$ & $\begin{array}{l}\text { Log pension income } \\
\text { (conditional) }\end{array}$ \\
\hline \multirow[t]{2}{*}{ Husband's age } & 0.001 & 0.001 & -0.009 \\
\hline & $(0.002)$ & $(0.001)$ & $(0.007)$ \\
\hline \multirow[t]{2}{*}{ Wife's age } & -0.003 & -0.003 & $-0.022^{*}$ \\
\hline & $(0.004)$ & $(0.002)$ & $(0.012)$ \\
\hline \multirow[t]{2}{*}{ HRS year 2004} & 0.047 & 0.022 & 0.088 \\
\hline & $(0.030)$ & $(0.014)$ & $(0.084)$ \\
\hline \multirow[t]{2}{*}{ HRS year 2008} & -0.016 & -0.007 & -0.019 \\
\hline & $(0.023)$ & $(0.010)$ & $(0.065)$ \\
\hline \multirow[t]{2}{*}{ Husband < than HS (educ reference HS) } & $-0.079^{\star \star \star}$ & $-0.051^{* * *}$ & $-0.432^{* * *}$ \\
\hline & $(0.028)$ & $(0.013)$ & $(0.083)$ \\
\hline \multirow[t]{2}{*}{ Husband some college } & 0.024 & -0.001 & 0.009 \\
\hline & $(0.027)$ & $(0.013)$ & $(0.076)$ \\
\hline \multirow[t]{2}{*}{ Husband college+ } & -0.026 & -0.002 & $0.322^{* * *}$ \\
\hline & $(0.028)$ & $(0.013)$ & $(0.077)$ \\
\hline \multirow[t]{2}{*}{ Wife < HS (educ reference HS) } & $-0.129^{\star \star \star}$ & $-0.026^{* *}$ & -0.040 \\
\hline & $(0.029)$ & $(0.013)$ & $(0.089)$ \\
\hline \multirow[t]{2}{*}{ Wife some college } & -0.037 & -0.010 & 0.020 \\
\hline & $(0.025)$ & $(0.012)$ & $(0.072)$ \\
\hline \multirow[t]{2}{*}{ Wife college+ } & 0.032 & 0.019 & $0.252^{* * *}$ \\
\hline & $(0.032)$ & $(0.014)$ & $(0.085)$ \\
\hline \multirow[t]{2}{*}{ Husband years worked all jobs } & $-0.002^{* \star \star}$ & $-0.001^{* * *}$ & $-0.003^{* *}$ \\
\hline & $(0.001)$ & $(0.000)$ & $(0.001)$ \\
\hline \multirow[t]{2}{*}{ Wife years worked all jobs } & 0.001 & $-0.000^{*}$ & -0.002 \\
\hline & $(0.001)$ & $(0.000)$ & $(0.002)$ \\
\hline \multirow[t]{2}{*}{ Husband S\&L $0-<10$ yrs (reference zero) } & $0.072^{* *}$ & $0.035^{\star *}$ & 0.061 \\
\hline & $(0.032)$ & $(0.015)$ & $(0.088)$ \\
\hline \multirow[t]{2}{*}{ Husband S\&L 10-<20 yrs } & $0.260^{* * *}$ & $0.072^{* \star *}$ & 0.181 \\
\hline & $(0.049)$ & $(0.022)$ & $(0.117)$ \\
\hline \multirow[t]{2}{*}{ Husband $S \& L 20-<30$ yrs } & $0.239^{* * *}$ & $0.171^{* * *}$ & $0.498^{* * *}$ \\
\hline & $(0.048)$ & $(0.022)$ & $(0.116)$ \\
\hline \multirow[t]{2}{*}{ Husband S\&L 30+ yrs } & $0.151^{* * *}$ & $0.152^{* * *}$ & $0.672^{* * *}$ \\
\hline & $(0.050)$ & $(0.023)$ & $(0.127)$ \\
\hline \multirow[t]{2}{*}{ Wife S\&L $0-<10$ yrs (reference zero) } & 0.041 & 0.003 & -0.068 \\
\hline & $(0.029)$ & $(0.013)$ & $(0.080)$ \\
\hline \multirow[t]{2}{*}{ Wife S\&L $10-<20$ yrs } & 0.035 & $0.034^{*}$ & $0.188^{*}$ \\
\hline & $(0.039)$ & $(0.018)$ & $(0.106)$ \\
\hline \multirow[t]{2}{*}{ Wife S\&L $20-<30$ yrs } & $0.128^{* * *}$ & $0.094^{* * *}$ & $0.511^{* * *}$ \\
\hline & $(0.048)$ & $(0.022)$ & $(0.120)$ \\
\hline
\end{tabular}


Wife S\&L 30+ yrs

Husband FED $0-<10$ yrs (reference zero)

Husband FED 10-<20 yrs

Husband FED $20-<30$ yrs

Husband FED $30+$ yrs

Wife FED 0-<10 yrs (reference zero)

Wife FED 10-<20 yrs

Wife FED $20-<30$ yrs

Wife FED $30+$ yrs

\begin{abstract}
0.086
\end{abstract}
R-squared

Standard errors in parentheses

${ }^{*} p<0.1$
(0.063)

0.007

(0.045)

$0.113^{*}$

(0.067)

0.140 **

(0.063)

$0.214^{* * *}$

(0.073)

$-0.014$

(0.044)

0.041

(0.077)

0.142

(0.093)

0.024

(0.116)

0.752 **

(0.293)

2640

0.074

$0.113^{* * *}$

(0.029)

$-0.008$

(0.021)

$0.093^{* * *}$

(0.031)

$0.242^{\text {*** }}$

(0.029)

$0.288^{* * *}$

(0.034)

$-0.037^{*}$

(0.020)

0.012

(0.035)

$0.225^{\text {*** }}$

(0.042)

0.094 *

(0.053)

$0.325^{\star *}$

(0.134)

2640

0.166

${ }^{* *} p<0.05$

Note: FED indicates years of service in Federal employment 
Table 12. Initial conditions for simulations

\begin{tabular}{lcccccc}
\hline & \multicolumn{2}{c}{ Singles } & \multicolumn{4}{c}{ Couples } \\
& \multicolumn{2}{c}{ Worked in S\&L } & \multicolumn{3}{c}{ Which spouse worked in S\&L } \\
\cline { 2 - 7 } & No & Yes & Neither & $\begin{array}{c}\text { One or } \\
\text { both }\end{array}$ & One & Both \\
\hline $\mathbf{N}$ & 570 & 206 & 663 & 459 & 355 & 104 \\
Respondent age & 68.4 & 68.3 & 68.3 & 68.5 & 68.5 & 68.5 \\
Spouse age & & & 70.8 & 71.2 & 71.3 & 71.1 \\
Initial consumption & 28,695 & 35,437 & 48,573 & 59,489 & 58,519 & 62,802 \\
Retirement income & 21,774 & 28,492 & 42,478 & 53,260 & 50,283 & 63,420 \\
$\quad$ Social Security & 13,746 & 14,427 & 27,365 & 26,902 & 27,261 & 25,679 \\
$\quad \begin{array}{l}\text { Pension } \\
\text { Annuities }\end{array}$ & 6,051 & 13,016 & 13,686 & 24,440 & 21,079 & 35,914 \\
Mean initial wealth & 1,977 & 1,049 & 1,773 & 1,776 & 1,885 & 1,437 \\
Median initial & 259,958 & 362,401 & 635,757 & 996,618 & $1,048,672$ & 818,933 \\
wealth & 81,390 & 147,917 & 328,865 & 472,664 & 471,363 & 476,354 \\
\hline
\end{tabular}

Note: Income and wealth in $2014 \$$

Table 13. Simulation results: single persons

\begin{tabular}{lcccc}
\hline & \multicolumn{4}{c}{ Worked in S\&L } \\
\cline { 2 - 5 } Cut to pension income & No & \multicolumn{3}{c}{ Yes } \\
\cline { 2 - 5 } & $\mathbf{0}$ & $\mathbf{0 \%}$ & $\mathbf{3 0 \%}$ & $\mathbf{5 0 \%}$ \\
\hline $\mathbf{N}$ & 570 & 206 & 206 & 206 \\
mean initial wealth & 260.0 & 362.4 & 362.4 & 362.4 \\
mean PV of earnings & 16.2 & 35.7 & 35.7 & 35.7 \\
mean PV retirement income & 241.5 & 325.3 & 284.4 & 257.1 \\
mean PV taxes & 42.8 & 74.2 & 61.3 & 53.4 \\
mean PV consumption & 297.8 & 389.7 & 389.7 & 389.7 \\
percent adequately prepared & $66.4 \%$ & $73.1 \%$ & $70.3 \%$ & $68.9 \%$ \\
mean wealth bequeathed & 177.9 & 260.6 & 232.5 & 213.2 \\
median wealth bequeathed & 68.2 & 150.8 & 125.9 & 101.6 \\
\hline
\end{tabular}

Note: thousands of 2014 dollars. "PV" means present value 
Table 14. Simulation results: couple households

\begin{tabular}{lcccc}
\hline & \multicolumn{4}{c}{ Worked in S\&L } \\
\cline { 2 - 5 } Cut to pension income & No & \multicolumn{3}{c}{ Yes } \\
\cline { 2 - 5 } & $\mathbf{0}$ & $\mathbf{0 \%}$ & $\mathbf{3 0 \%}$ & $\mathbf{5 0 \%}$ \\
\hline $\mathbf{N}$ & 663 & 459 & 459 & 459 \\
mean initial wealth & 635.8 & 996.6 & 996.6 & 996.6 \\
mean PV of earnings & 37.9 & 61.2 & 61.2 & 61.2 \\
mean PV retirement income & 528.1 & 692.9 & 625.4 & 580.4 \\
mean PV taxes & 141.8 & 268.9 & 243.6 & 227.7 \\
mean PV consumption & 577.0 & 750.6 & 750.8 & 750.8 \\
percent adequately prepared & $88.5 \%$ & $89.9 \%$ & $88.4 \%$ & $86.9 \%$ \\
mean wealth bequeathed & 483.8 & 732.1 & 689.8 & 660.7 \\
median wealth bequeathed & 324.0 & 459.9 & 419.6 & 389.7 \\
\hline
\end{tabular}

Note: "Couple household worked in S\&L" means that one or both spouses worked in S\&L; thousands of 2014 dollars. "PV" means present value

Table 15. Percent adequately prepared for retirement; cohort analysis

\begin{tabular}{lcccc}
\hline \multirow{2}{*}{ worked in S\&L } & \multicolumn{3}{c}{ Cohort } & \multirow{2}{*}{ All } \\
\cline { 2 - 4 } & $\begin{array}{l}\text { HRS } \\
\mathbf{2 0 0 4}\end{array}$ & $\begin{array}{c}\text { HRS } \\
\mathbf{2 0 0 8}\end{array}$ & WB 2014 & \\
\hline Singles & & & & \\
\hline No & $70.4 \%$ & $64.7 \%$ & $66.4 \%$ & $66.4 \%$ \\
Yes & $81.3 \%$ & $70.4 \%$ & $72.9 \%$ & $73.1 \%$ \\
All & $73.1 \%$ & $66.3 \%$ & $68.1 \%$ & $68.2 \%$ \\
Couples (either or both) & & & & \\
\hline No & $94.9 \%$ & $86.8 \%$ & $88.1 \%$ & $88.5 \%$ \\
Yes & $89.9 \%$ & $90.5 \%$ & $88.7 \%$ & $89.9 \%$ \\
All & $92.8 \%$ & $88.3 \%$ & $88.3 \%$ & $89.0 \%$ \\
\hline
\end{tabular}




\section{Appendix}

We applied the following sample selection criteria:

HRS-2004

1a Individual was: a single respondent in 2004, and between the ages of 67 and 72 (inclusive) in 2004, or:

1b Individual was: a respondent in a partnership in 2004, and between the ages of 67 and 72 (inclusive) in 2004, or:

1c Individual was in a partnership with someone satisfying condition (1b) in 2004.

HRS-2008

2a Individual was: a single respondent in 2008 and between the ages of 67 and 72 (inclusive) in 2008 , and did not satisfy conditions (1a)-(1c), or:

2b Individual was: a respondent in a partnership in 2008, and between the ages of 67 and 72 (inclusive) in 2008, and did not satisfy conditions (1a)-(1c), or:

2c Individual did not satisfy conditions (1a)-(1c), and was in a partnership with someone satisfying condition (2b) in 2008.

HRS-2014

2a Individual was: a single respondent in 2014 and between the ages of 67 and 72 (inclusive) in 2014, and did not satisfy conditions (1a)-(2c), or:

2b Individual was: a respondent in a partnership in 2014, and between the ages of 67 and 72 (inclusive) in 2014, and did not satisfy conditions (1a)-(2c), or:

2c Individual did not satisfy conditions (1a)-(2c), and was in a partnership with someone satisfying condition (3b) in 2014. 